\title{
THE MECHANICAL PROPERTIES OF A MIXTURE OF HIGH DENSITY POLYETHYLENE AND CALCIUM CARBONATE DEDICATED FOR PACKAGING
}

\author{
Jacek Garbarski, Mariusz Fabijański
}

\begin{abstract}
$\mathrm{S}$ u m m a r y
Packaging made of polymeric materials is one of the most important branches of polymer processing. A very essential task which is to be solved in this area, is searching for new materials which would allow for lowering the cost while still maintaining good mechanical properties. In the current paper the attempt to decrease the cost of the HDPE intended for blow moulding of packaging by admixing $\mathrm{CaCO}_{3}$ filler is presented. The dependence of mechanical properties upon the filler content is also shown.
\end{abstract}

Keywords: high density polyethylene, packaging, calcium carbonate

\section{Właściwości mechaniczne mieszaniny polietylenu dużej gęstości i węglanu wapnia przeznaczonej na opakowania}

$$
\text { Streszczenie }
$$

Opakowania wykonane z materiałów polimerowych stanowią duży obszar przetwórstwa materiałów polimerowych. Podstawowym zadaniem w tym zakresie jest wciąż poszukiwanie nowych materiałów umożliwiających zmniejszenie kosztów i zachowanie dobrych właściwości mechanicznych. W pracy podjęto próbę zmniejszenia kosztów HDPE przeznaczonego do wytwarzania opakowań przez wprowadzenie $\mathrm{CaCO}_{3}$ jako wypełniacza. Określono zmianę właściwości mechanicznych tych materiałów w zależności od zawartości napełniacza.

Słowa kluczowe: polietylen o dużej gęstości, opakowania, węglan wapnia

\section{Introduction}

One of the biggest branches predominated by polymers is the packaging industry. The continuous increase of demand for theses products results in an increase in output and, consequently, bigger flood of the waste material which pollutes the environment. Apart from that, the permanent increase of crude oil and coal prices makes the packaging more and more costly. Such branches like food and cosmetics industries order sophisticated shapes of cans, bottles, boxes

Address: Jacek GARBARSKI, DSc. Eng., Mariusz FABIJAŃSKI, PhD. Eng., Warsaw University of Technology, 02-524 Warsaw, Narbutta 85, e-mail: mfabijan@wip.pw.edu.pl 
etc. which itself is a price rising factor. It is not rare that the price of packaging is equal to the one of the medium which is to be contained $[1,2]$.

Thus, it is not surprising that packaging manufacturers are searching for new and inexpensive solutions to lower the packaging cost. One of the simplest ways is applying the mineral fillers for the sole purpose of decreasing the cost of the material without causing major loses of mechanical properties and without affecting the content of the packaging. The most popular fillers of this kind are magnesium oxide, magnesium carbonate, calcium compounds and certain kinds of phosphorus carbonate. They are used for food, cosmetics, pharmaceutical and chemical industries [3, 4].

The most popular, however, is calcium carbonate $\mathrm{CaCO}_{3}$ known as chalk. It is a solid body hardly soluble in water, yet soluble in $\mathrm{CO}_{2}$ saturated water and in ammonium chloride solution. The melting temperature is $128^{\circ} \mathrm{C}$. At $900^{\circ} \mathrm{C}$ it is decomposed into calcium oxide $(\mathrm{CaO})$ and carbon dioxide $\mathrm{CO}_{2}$. Naturally it occurs as calcite - the hardest crystalline form of calcium carbonate. It is mainly used in ceramic and glass industries [4-8]. From the natural chalk, the chalk for writing on the blackboard is produced. As the precipitated chalk it is an additive in manufacturing paints, paper, rubber, toothpaste and etc. It should be stressed that it is very cheap $[1,2]$.

\section{Materials used for the tests}

Calcium carbonate (commercial symbol OMYA), manufactured by Swiss firm OMYA was used as the filler. This product has the form of the masterbatch containing $98 \%$ calcium carbonate which makes it easier to introduce to the polymer. This filler has all required certificates of safety and contact with food. The polymer to be modified was high density polyethylene. Due to its properties (easy processing, introducing dyes and other admixtures) it is (beside PP and PET) the most popular packaging material in the food industry. The tested material was HDPE of the commercial name TIPELIN BA 550-13, manufactured by Tiszai Vegyi Kombinat Nyrt (Hungary). It is intended for blow moulding. Its melt flow ratio MFR $=0.3-0.4 \mathrm{~g} / 10 \mathrm{~min}$ (at $2.16 \mathrm{kG}, 190{ }^{\circ} \mathrm{C}$ ).

Five mixtures of the following $\mathrm{CaCO}_{3}$ contents were prepared:

- $5 \% \mathrm{CaCO}_{3}+95 \% \mathrm{HDPE}$

- $10 \% \mathrm{CaCO}_{3}+90 \% \mathrm{HDPE}$

- $20 \% \mathrm{CaCO}_{3}+80 \% \mathrm{HDPE}$

- $30 \% \mathrm{CaCO}_{3}+70 \% \mathrm{HDPE}$

- $35 \% \mathrm{CaCO}_{3}+65 \% \mathrm{HDPE}$

The paddle shaped specimens for testing mechanical properties were injection moulded. The properties underwent axial tensile test in accordance with PN-EN ISO 527-2 [9]; and the hardness test in accordance with PN-EN ISO 2039-2 [10]. 


\section{Results of the tests}

Figures 1 and 2 present the dependence of the maximum tensile stress and the corresponding elongation, respectively.

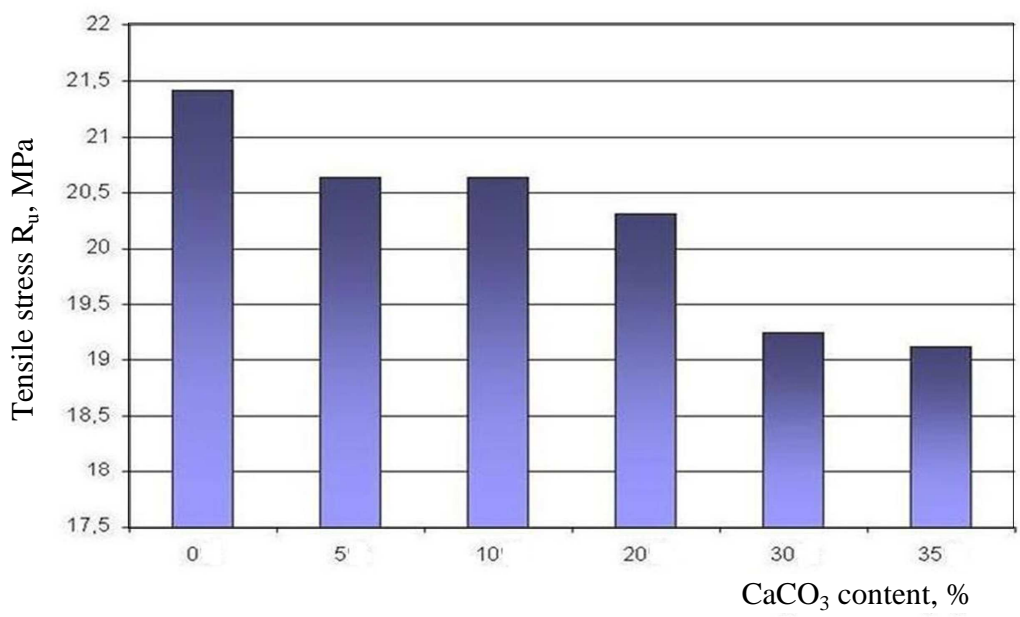

Fig. 1. Maximum tensile stress $\mathrm{R}_{\mathrm{u}}$ versus $\mathrm{CaCO}_{3}$ content

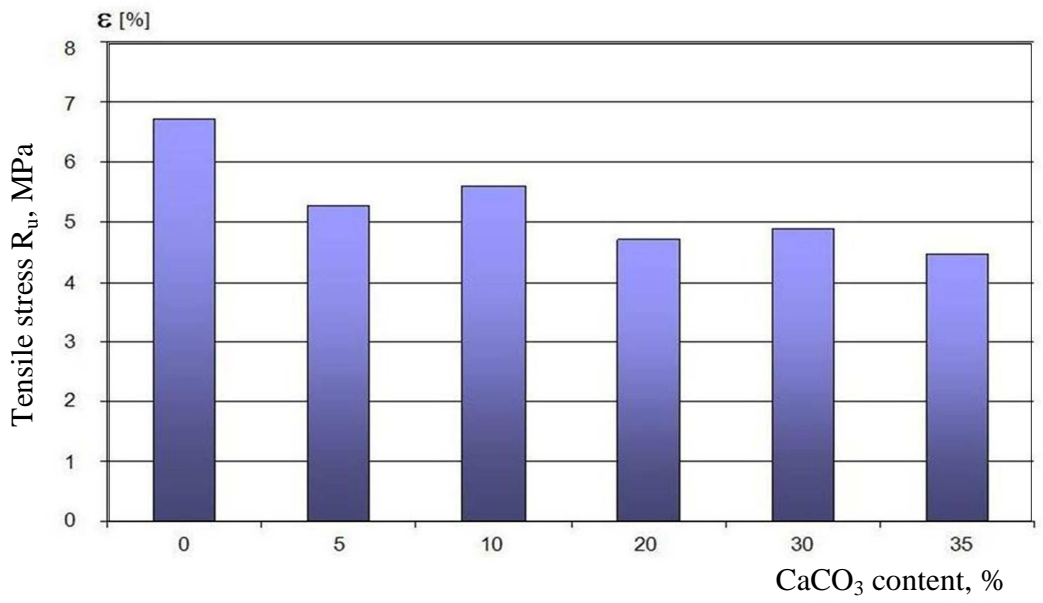

Fig. 2. Elongation at $\mathrm{R}_{\mathrm{u}}$ versus $\mathrm{CaCO}_{3}$ content

Only a minor drop of mechanical resistance (from 21 to $19 \mathrm{MPa}$ ) and of elongation (from 6.7 to $4.5 \%$ ) can be seen at both mentioned figures. In Figure 3 
the hardness of the material depending on the $\mathrm{CaCO}_{3}$ contents is presented. The hardness does not increase much which means that the material still remains soft. The results of all the tests are summarized in Table 1.

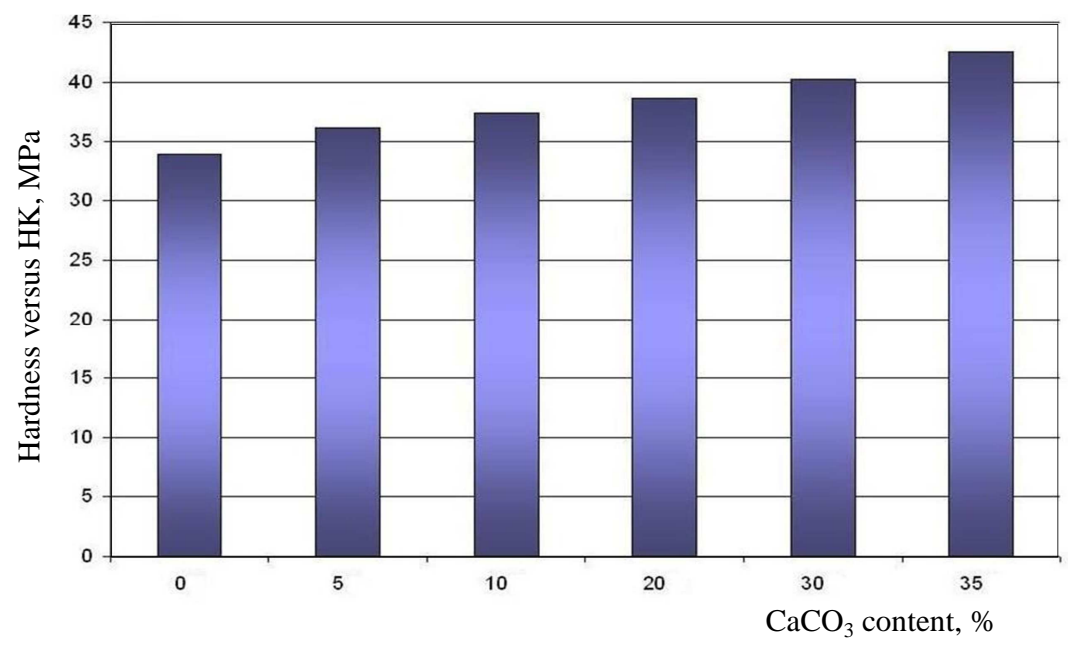

Fig. 3. Hardness versus $\mathrm{CaCO}_{3}$ content

After testing the material as described above, a primary series of $250 \mathrm{ml}$ bottles were manufactured using the extrusion-blow moulding technology. It was noticed that the bottles made of mixture containing $20 \%$ or more $\mathrm{CaCO}_{3}$ broke along the welded line even at slight pressing by hand. This of course disqualifies the material which means that the $\mathrm{CaCO}_{3}$ content should not exceed $10-15 \%$

Another important factor is the change of colour. Many companies demand that the packaging should be either natural colour or snow-white which can be obtained by admixing small quantity of the appropriate dye. In case of the material with $\mathrm{CaCO}_{3}$ additive, it is easier to pigment the material to any other colour than recover the original snow-white look. Due to the high price of the white pigment, it can not be used for this purpose because the aim of this paper is lowering the material cost.

The addition of calcium carbonate reduces the unit cost of packaging. Assuming that the cost of the filler is half of the polymer cost, we can estimate if the saving on material is possible. It should be remembered that a compromise between the amount of the filler and the minimum required mechanical properties must be maintained. Optimum properties are obtained at the content ranging from 10 to $15 \% \mathrm{CaCO}_{3}$. At first it may seem that the savings are not remarkable but at large quantities of the processed material cost savings are considerable. 
Table 1. Statement of all experimental results

\begin{tabular}{|c|c|c|c|c|}
\hline $\begin{array}{c}\text { Mixture } \\
\text { number }\end{array}$ & $\begin{array}{c}\text { Content } \\
\mathbf{C a C O}_{\mathbf{3}}, \boldsymbol{\%}\end{array}$ & $\begin{array}{c}\text { Max. tensile } \\
\text { stress } \mathbf{R}_{\mathbf{u}}, \mathbf{M P a}\end{array}$ & Elongation $\boldsymbol{\varepsilon}, \boldsymbol{\%}$ & $\begin{array}{c}\text { Hardness HK, } \\
\mathbf{M P a}\end{array}$ \\
\hline 1 & 0 & $21 ., 4$ & 6.72 & 34.0 \\
\hline 2 & 5 & 20.6 & 5.27 & 36.2 \\
\hline 3 & 10 & 20.7 & 5.60 & 37.4 \\
\hline 4 & 20 & 20.3 & 4.71 & 40.2 \\
\hline 5 & 30 & 19.2 & 4.90 & 42.6 \\
\hline 6 & 35 & 19.1 & 4.40 & 42.6 \\
\hline
\end{tabular}

\section{Conclusions}

Calcium carbonate used as a filler to HDPE intended for blow moulding of bottles can be applied as the cost-reducing component provided that its amount would not exceed certain limitation. Otherwise, the mechanical strength of the manufactured bottles is unacceptable. As the admixture of $\mathrm{CaCO}_{3}$ would not make it possible to obtain a snow-white material, it can be accepted only for products where the ideal white is not required. Under such circumstances, if a company can accept any other colour than snow-white, the yearly saving on the material would go to tens of thousands in Polish currency. In the present case, the best results were obtained for the filler content ranging from 10 to $15 \%$.

\section{References}

[1] H. ŻAKOWSKA: Problemy przedsiębiorców związane z odpadami opakowaniowym. Opakowanie, 4(2005).

[2] H. ŻAKOWSKA: Rynek odpadów opakowaniowych. Recykling, 15(2002)9.

[3] P. JAKUBOWSKA, A. KLOZIŃSKI, T. STERZYŃSKI: Właściwości reologiczne wysoko-napełnionych kompozytów poliolefin. ATR Bydgoszcz, Zeszyty Naukowe, Chemia i Technologia Chemiczna, z. nr 11, Bydgoszcz 2006, 57-60.

[4] P. JAKUBOWSKA, T. STERZYŃSKI: Właściwości mechaniczne folii poliolefinowych o wysokim stopniu napełnienia węglanem wapnia. Czasopismo Techniczne. Mechanika, 103(2006)6, 231-234.

[5] A. CHAFIDZ, A. ILIAS, M.E. MOHSIN, R. ELLEITHY, S. AL-ZAHRANI: Atomic force microscopy, thermal, viscoelastic and mechanical properties of $\mathrm{HDPE} / \mathrm{CaCO}_{3}$ nanocomposites. Journal of Polymer Research, 19(2012)9860.

[6] Yu-Lin Yang, Shu-Lin Bai, Christian G'Sell, Jean-Marie Hiver: Mechanical properties and volume dilatation of $\mathrm{HDPE} / \mathrm{CaCO}_{3}$ blends with and without impact modifier. Polymer Engineering \& Science, 46(2006)11, 1512-1522.

[7] Z. BARTCZAK, A.S. ARGON, R.E. COHEN, T. KOWALEWSKI: The morphology and orientation of PE in films of sub-micron thickness crystallized in contact with calcite and rubber substrates. Polymer, 40(1999), 2367. 
[8] D.M. ANSARI, R.P. HIGGS: The Influence of mineral fillers on the processing of LLDPE films. Proc. TAPPI Polymers, Laminations, \& Coatings Conference, 1997, 173.

[9] PN-EN ISO 527-2:2012. Tworzywa sztuczne - Oznaczanie właściwości mechanicznych przy statycznym rozciąganiu - Część 2: Warunki badań tworzyw sztucznych przeznaczonych do prasowania, wtrysku i wytłaczania.

[10] PN-EN ISO 2039-2:2002. Tworzywa sztuczne - Oznaczanie twardości - Część 2: Twardość Rockwella.

Received in January 2013 